Volume 3

Issue 2 -- Infectious Disease

Article 6

4-22-2016

\title{
Disease-Causing Fungi in Homes and Yards in the Midwestern United States
}

Dennis J. Baumgardner

Follow this and additional works at: https://aah.org/jpcrr

Part of the Bacterial Infections and Mycoses Commons, Environmental Microbiology and Microbial Ecology Commons, Infectious Disease Commons, Other Ecology and Evolutionary Biology Commons, and the Other Immunology and Infectious Disease Commons

\section{Recommended Citation}

Baumgardner DJ. Disease-causing fungi in homes and yards in the Midwestern United States. J Patient Cent Res Rev. 2016;3:99-110. doi: 10.17294/2330-0698.1053

Published quarterly by Midwest-based health system Advocate Aurora Health and indexed in PubMed Central, the Journal of Patient-Centered Research and Reviews (JPCRR) is an open access, peer-reviewed medical journal focused on disseminating scholarly works devoted to improving patient-centered care practices, health outcomes, and the patient experience. 


\title{
Disease-Causing Fungi in Homes and Yards in the Midwestern United States
}

\author{
Dennis J. Baumgardner, MD \\ Aurora University of Wisconsin Medical Group, Aurora Health Care, Milwaukee, Wl; Department of Family Medicine \\ and Community Health, University of Wisconsin School of Medicine and Public Health, Madison, Wl; Center for Urban \\ Population Health, Milwaukee, WI
}

\begin{abstract}
A number of fungal pathogens that may result in a variety of human diseases are found in residential homes and yards. The growth of these microscopic fungi is often favored by particular characteristics of the dwelling and nearby outdoor environment. Evolved virulence factors or increased ability of specific fungi to grow in diverse, and sometimes harsh, microenvironments presented by the domestic environment may promote growth and pathogenesis. Infection may occur by inhalation or direct inoculation and include endemic fungi in addition to opportunistic or emerging species. Systemic or locally aggressive fungal infections are particularly likely and may be life-threatening in those with compromised immune systems. Allergic disease may include sinusitis, pneumonitis and immediate hypersensitivity. Controversial topics include mycotoxins, volatile organic compounds and sick building syndrome. This narrative review describes the usual presentations, domestic environmental sources, prevention techniques and risk of acquiring these diseases in the Midwestern United States. (J Patient Cent Res Rev. 2016;3:99-110.)
\end{abstract}

Keywords mycoses; fungi; histoplasmosis; blastomycosis; sporotrichosis; Aspergillus

A number of potential fungal pathogens are found in residential homes and yards. These microscopic fungi may result in a variety of human disease. This includes potentially fatal systemic fungal infections, traumatic wound infections, allergic manifestations, exacerbations of asthma, and sometimes vague, troubling, nonspecific signs and symptoms. Fortunately, these instances are relatively uncommon; however, domestically acquired fungal-related disease in humans may be seen more frequently as the proportion of immunocompromised patients living at home increases. Except for dermatophytes, most such fungal infections were apparently uncommon until the use of immunosuppressive agents and drugs in the second half of the 20th century. ${ }^{1,2}$ No doubt, significant improvements in the clinical and laboratory diagnosis of fungal infections in the last several decades has increased recognition of these diseases.

Correspondence: Dennis J. Baumgardner, MD, Aurora Sinai Medical Center, 1020 N. 12th Street, \#4180, Milwaukee, WI, 53233, T: 414-219-5191, F: 414-219-3116, Email: dennis.baumgardner@aurora.org
Allergic, toxic and irritant diseases from inhaled mold spores have been known since antiquity. ${ }^{3}$ The purpose of this narrative review is to describe disease that may result from fungal infection or exposure in one's home or yard, and to increase clinician awareness that such illnesses may occur without significant occupational, recreational or exotic outdoor exposure. Included are potentially pathogenic fungi found in microenvironments immediately outside the home as well as on indoor or outdoor household surfaces, or that are associated with large appliances or other home furnishings. This article will not include dermatophyte or fungal infections acquired through contaminated or colonized food substances or personal care items, nor will it provide diagnostic or treatment detail for the diseases discussed. Rather, it is an overview of the genesis and clinical manifestations of the more common (e.g. blastomycosis) or emerging (e.g. black yeasts) types of fungal-related diseases and recent societal concerns (e.g. sick building syndrome) one might encounter at home in the Midwestern United States.

\section{Home and Yard Microbial Ecology}

Residential Soil and Building Materials: Yards contain some combination of plants, rocks/concrete/stone, decaying small animal carcasses and waste, processed 
natural materials such as decorative bark, fencing and, the principal component, soil. Soil is a mixture of mineral and organic (humus) constituents. Soil-particle surfaces, pore spaces and nutrient-rich zones such as the rhizosphere (soil surrounding a plant root) form particular habitat for microorganisms, often in biofilms. ${ }^{4-8}$ The quantity and types of fungi in a specific soil microenvironment are determined by a complex interaction of physical attributes (nutrients, moisture, sunlight, temperature, $\mathrm{pH}$ level and redox potential) and competing organisms (other fungi, bacteria, archaea, viruses and larger organisms such as amoebae or worms) (Figure 1). ${ }^{4-9}$

Factors contributing to the sometimes extreme environment of residential soil include applied herbicides, pesticides and other chemicals, temperature differentials due to the nearby heated dwelling and radiation of heat from sunlit patios, tannins from new decorative bark, etc. Concrete or stone are even more extreme environments for microorganisms. The ability of fungal pathogens to grow in such diverse environmental stress may explain their ability to "opportunistically" inhabit a plethora of challenging niches, including the human body. ${ }^{10,11}$ Pathogenic fungi may be indigenous to the native soil or enter the yard through animal deposits, manure or purchased materials. ${ }^{9}$

Home exterior and interior building materials, surfaces and appliances can be even more extreme microenvironments for fungi than the surrounding yard. ${ }^{12}$ Kitchens, bathrooms, metals, hard polymers, silicones, antiseptics and cleaning products cause oxidative and other stress on microbial cells. Additionally, indoor aromatic pollutants may be metabolized by certain black yeasts. As with residential soil, successful indoor colonization by a fungus is determined by its ability to tolerate the particular physiochemical properties of the building materials or surfaces and derive sufficient nutrients from them. ${ }^{12}$ Despite the significant differences in appearance, indoor surface habitats are often similar to extreme natural outdoor environments. ${ }^{12}$ The highmoisture, high-temperature, detergent-laden, alkaline environment of a household dishwasher is one example. ${ }^{13}$ The ability to develop so-called "extremotolerance" may favor genetically and physiologically adaptable "generalist" fungi such as black yeast ${ }^{12,14}$ and Aspergillus spp. (both perhaps ancestrally rock surface inhabitants) ${ }^{11}$ as well as Blastomyces spp. ${ }^{15}$

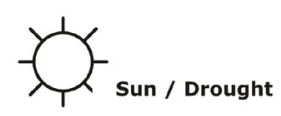

Microbial Soil ECOLOGY

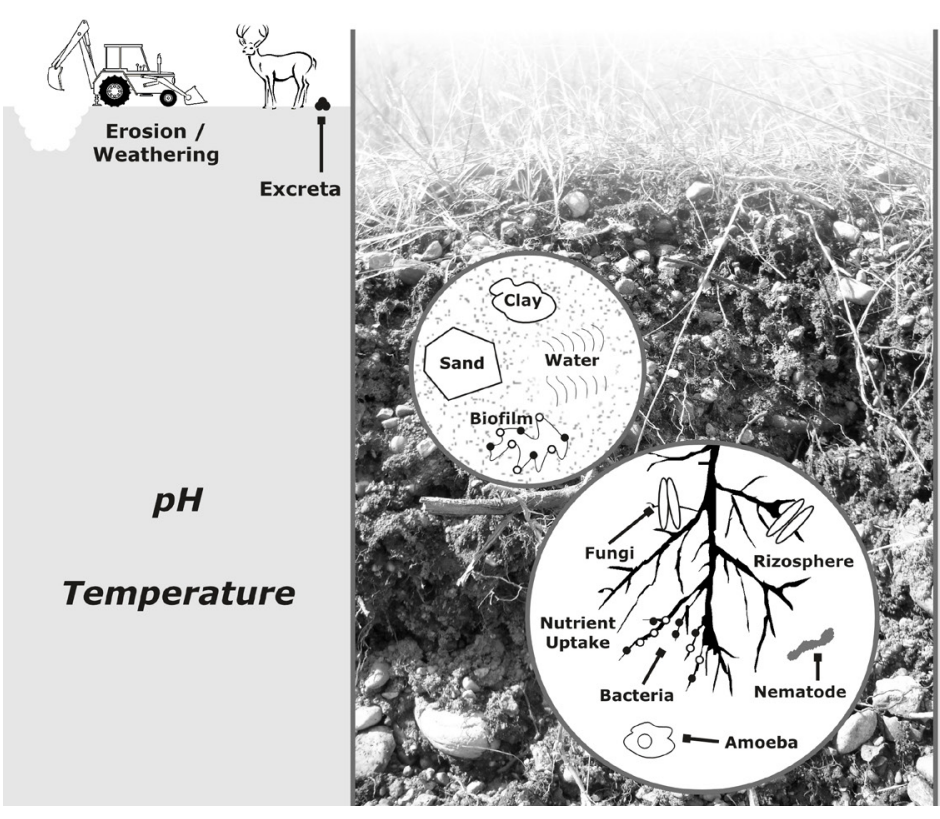

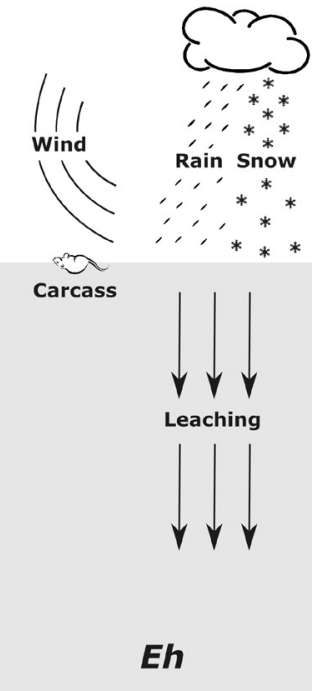

Moisture Content
Figure 1. Microbial soil ecology. Pictorial representation of factors determining distribution of bacterial and fungal microorganisms in soil. Side panels represent climatic, physical and geobiochemical factors. Central panel includes a magnification (upper circle) representing soil particles, pore spaces and bacteria in biofilm, and another (lower circle) representing the rhizosphere and associated bacteria and fungi (and amoebae and nematodes). (Reproduced from Baumgardner DJ. Soilrelated bacterial and fungal infections. J Am Board Fam Med. 2012;25:734-44, by permission of the American Board of Family Medicine.) 
Climate Conducive to Fungi: Most environmental fungi cannot grow at human body temperatures. An in vitro study of 4,802 fungal strains representing 144 genera revealed that each $1^{\circ} \mathrm{C}$ temperature increase between $30^{\circ}$ and $40^{\circ}$ restricted the growth of approximately $6 \%$ additional fungal strains. ${ }^{1}$ In addition, our complex, redundant immune system inhibits a majority of potentially pathogenic fungal species. Again, the ability of a particular organism to survive our warm-blooded, slightly alkaline internal environment may be the result of harsh selective factors in domestic outdoor and indoor environments including thermal, physical, chemical, oxidative and competitive stresses. ${ }^{1,2,10,12,14}$ In addition to thermal tolerance and biofilms (common among black yeasts and Candida spp.), ${ }^{12,16}$ virulence factors for human invasion may have originated to counterattack bacteria, amoeba, nematodes and other organisms in the natural environment. ${ }^{1,12}$ As Gostinčar and colleagues suggested, "We have made our indoor (surface) environments prohibitive for the growth of the majority of microbes. However, the most resistant ones (and as such possibly the most dangerous) have succeeded in surviving and adapting." 12

Mold growth and moisture problems are common in homes. Visible mold may be identified in rooms whether a problem is suspected or not. It is frequently found on windowsills, refrigerator seals, spaces underneath kitchen sinks and air vents. Establishing normal levels for indoor fungal load has been difficult and controversial. ${ }^{17}$ A North Carolina study suggested that heating, ventilation and air conditioning (HVAC) systems and associated ductwork may transmit mold spores from the crawl space to the home interior. ${ }^{18}$ A recent university housing study from California examined fungi on residential surfaces including kitchens and bathroom drains, windowsills and the skin of human inhabitants. This housing had no reported mold problems and did not allow pets. The surfaces yielded a fungal profile similar to that expected in the outdoor air of that locale, and differed by surface type. Fungi typical of indoor air, such as Cladosporium and Cryptococcus, were found on windowsills. Drains yielded thermotolerant fungi including Candida, Exophiala and Fusarium. Human forehead skin contained a variety of indoor- and outdoorassociated fungi. ${ }^{19}$ In a separate study, fungi, especially Aspergillus, were identified on home pillows. ${ }^{20}$
Other Environmental Factors: Pathogenic fungi may be introduced into the respiratory tract via bioaerosols (e.g. wind- or fan-borne spores, dusts and airborne soil or construction particles). Concentrations of fungal spores (up to and exceeding 100,000 spores $/ \mathrm{m}^{3}$ ) vary widely by geographic factors like temperature, moisture, wind, photoperiod and time of day. Common outdoor spores include those from Cladosporium, Alternaria, Penicillium, Aspergillus and others. Indoor spore levels are generally $40-80 \%$ of outdoor levels and reflective of outdoor species. Humidity, inadequate ventilation and increased ambient temperature can increase the fungal burden of a home. A number of indoor sources, such as plants, pets and mold-transporting footwear and clothing, also may contribute mold. ${ }^{17,21}$ Fungal pathogens can enter humans by traumatic inoculation into wounds. Simultaneously introduced dirt-related minerals may promote infection by suppressing local host defenses. ${ }^{6}$ Much less is known about the contribution to human disease of fungal toxins and volatile organic compounds released by fungi. ${ }^{21-24}$

On occasion, fungal infections may be acquired in one's home or yard from a source external to one's property, as in the case of an earthquake or dust storm. ${ }^{25,26}$ In the Midwest, both histoplasmosis and blastomycosis apparently have been acquired at home via airborne spores from a more remote source..$^{27-30}$ Cases of mucormycosis caused by Apopphysomyces trapeziformis were reported following a 2011 tornado in Joplin, Missouri. ${ }^{31}$

\section{Fungal Infections Primarily Acquired Outdoors \\ Histoplasmosis: The thermally dimorphic systemic} fungus, Histoplasma capsulatum, is endemic to the Midwest, where a number of histoplasmosis outbreaks have occurred. ${ }^{27,32}$ Evidence of exposure is found in a majority of residents in this region. ${ }^{33}$ Histoplasmosis, a primary pulmonary disease, is often asymptomatic. The intensity of the acute pneumonia likely correlates with the burden of inhaled conidia. Pulmonary or mediastinal masses, nodules, granulomas, fibrosis or pericarditis may result. Arthralgias or erythema nodosum may be seen. Acute heavy-inoculum pneumonia may be severe and require mechanical ventilation. A bilateral, reticulonodular pattern may be seen on chest X-ray or computed tomography. The fungus may disseminate in any pulmonary infection to a variety of organ systems 
(liver, spleen, bone, lymph nodes, central nervous system, etc.). Patients with underlying lung disease may experience chronic, progressive (cavitary) pulmonary histoplasmosis.

H. capsulatum can cause opportunistic infections. ${ }^{27,32,34}$ Histoplasmosis-associated eye disease, a choroiditis often associated with serotype HLA-B7, is relatively unique to the Midwest. Patients are often asymptomatic unless scarring involves the optic nerve or fovea. A precise etiologic link to $H$. capsulatum as the causative agent is still lacking. ${ }^{32}$ Pediatric disease is generally asymptomatic or mild (fever, cough, chest pain and malaise) and limited to 2 weeks in duration, although fatigue may linger. ${ }^{32}$ Localized skin disease following direct inoculation is rare. ${ }^{30}$

Growth of $H$. capsulatum is associated with $67-87 \%$ relative humidity, 90-127 cm of annual precipitation and mean soil temperatures of $22-29^{\circ} \mathrm{C} .{ }^{9}$ The latter may explain the relative paucity of infections in the most upper portions of the Midwest. H. capsulatum lives in soil that is generally moist, acidic and high in nitrogen, carbohydrate and cationic salt content, particularly (but not exclusively) in association with bat or bird guano. ${ }^{27,30}$ The ability of Histoplasma to assimilate uric acid and related compounds may explain the latter association. ${ }^{35}$ Conidia (spores) are inhaled following nearby soil disturbance as a result of construction or excavation or around potted plants. ${ }^{27,36-39}$ The problem of birds nesting in large numbers on, in or near buildings is a particular problem. The large amounts of guano and nesting materials may remain for years and pose a health hazard during removal or even fairly minimal disturbance or dust formation. ${ }^{30}$

While $H$. capsulatum spores inhaled from one's yard are often generated by a more remote source (often part of a large urban outbreak), ${ }^{30}$ there have been specific instances of exposure from sources on the property. Examples include infection of homeowners and tenants during demolition of the exterior walls of an old brick house that included bird or bat guano, ${ }^{40}$ infection of visiting relatives at a family reunion in Iowa exposed to an old barn, ${ }^{41}$ and 10 sporadic cases from the same duplex housing complex on an Air Force base in central Illinois. ${ }^{42}$ In the latter cases, several soil sites about the complex were culture-positive for $H$. capsulatum. In the former two examples, ${ }^{40,41}$ environmental testing was apparently not attempted.

Blastomycosis: Blastomycosis is a potentially lifethreatening systemic and cutaneous fungal infection. ${ }^{43,44}$ Pulmonary disease is the most common manifestation, and it has a broad differential diagnosis. ${ }^{45}$ The pneumonia may be asymptomatic, chronic or subacute, or sometimes rapidly progressive with adult respiratory distress syndrome and death. ${ }^{43}$ Acute or chronic dissemination of the fungus to skin, brain, genitourinary system, bones or virtually any organ system may result. ${ }^{43,45}$

Blastomycosis is caused by Blastomyces dermatitidis or the newly discovered cryptic species Blastomyces gilchristii; ${ }^{46}$ both are dimorphic fungi endemic to the Midwest. Annual incidence ranges from $<1-100$ per 100,000 persons. Blastomyces occurs in and near soil microenvironments. Soil isolations ${ }^{47}$ and sites of likely exposure, including home sites, are often associated with sand soils, nearby waterways and animal excreta. It also appears to be a survivor of harsh or changing environmental conditions and may utilize a wide variety of substrates. ${ }^{48}$ It is proposed that the ability to grow and sporulate in carbon-poor, high-ammonia environments may be a key to its competitive success. ${ }^{15}$ Preceding precipitation and environmental temperatures may impact the occurrence of Blastomyces. ${ }^{49,50}$ No animal reservoir has been identified. ${ }^{51}$ Except for rare inoculation disease (usually localized to the skin), fungal spores (conidia) enter the body upon inhalation from the environment into the lungs. Sources of conidia include wind- or excavation-generated dusts, disturbance of soil or other microenvironments and likely moisture-induced natural spore release from the local environment. $28,29,43,52,53$

While we feel there is good evidence that blastomycosis may be acquired on one's own property, and others have concurred,${ }^{54}$ some have disputed this hypothesis. ${ }^{55,56}$ Evidence includes case studies ${ }^{54,57}$ and repeated cases of blastomycosis at the same home site with different families; ${ }^{58}$ several studies that failed to implicate specific outdoor or occupational activities with acquisition of blastomycosis in most cases, ${ }^{59-61}$ and the isolation of $B$. dermatitidis from an abandoned house $\mathrm{e}^{62}$ and $20 \mathrm{~m}$ from a human home in northern Wisconsin. ${ }^{47}$ Evidence, therefore, has been largely circumstantial. In-home cultures have been otherwise negative, ${ }^{57,58}$ but 
$B$. dermatitidis is exceedingly difficult to culture from the environment. ${ }^{47,57}$

Sporotrichosis: Sporotrichosis is an uncommon subacute orchronic mycosis. In normal hosts, it is primarily a local lymphocutaneous infection resulting from direct environmental inoculation (thorns, splinters, cuts, etc.). Days or weeks later, a papule forms at the site of inoculation, becomes nodular and may ulcerate. Further nodules typically appear along the lymphatic distribution of that body site. This ascending lymphangitis picture also may be caused by nocardosis, atypical mycobacteria, leishmaniais and cutaneous anthrax. ${ }^{63}$ Osteoarticular disease may occur by direct inoculation or disease extension. Extensive cutaneous and systemic dissemination often occurs in untreated patients with underlying disease (alcoholism, acquired immune deficiency syndrome, diabetes or chronic obstructive pulmonary disease). Subacute or chronic pulmonary disease may follow, usually in the immunocompromised, through dissemination from the lymphatics or direct inhalation of conidia. ${ }^{63}$

The etiologic dimorphic fungus Sporothrix schenckii (and related strains) is found worldwide in soil, vegetation, sphagnum moss, potting soil, decaying wood, cornstalks, hay and several warm-blooded animals. Exposure to infected cats also may result in disease through scratches, bites or contact with a lesion on the cat. ${ }^{63-65}$ Unlike human lesions where the number of $S$. schenckii organisms may be low, cat lesions may have a very high fungal burden that allows transmission through lesion contact or splash without penetrating injury. ${ }^{63}$ Sporotrichosis may be acquired in the yard or home. A large multistate outbreak took place in 1988 related to sphagnum moss harvested in Wisconsin. ${ }^{6}$ A number of victims were patients who had received seedlings for their home sites. S. schenckii was cultured from five samples of unopened moss bales from one implicated nursery. Another outbreak was epidemiologically associated with bales of hay from a Halloween haunted house (there was no residual hay to culture, and cultures from the implicated fields 5 months after exposure were negative for S. schenckii). ${ }^{67}$ Such bales are often purchased for yard decorations. The author is personally acquainted with a poorly controlled diabetic who died of disseminated sporotrichosis acquired via a thorn puncture from her home garden in Illinois. In our own health system's patient database (representing several hundred thousand individuals), there were 15 cases of sporotrichosis diagnosed on clinical grounds from 2000 to 2009. All but one had upper extremity disease. Of these 15 suspected cases, 5 had confirmed thorn punctures and 3 had exposure to other outdoor activity risks. ${ }^{68}$

Other Mycoses: A variety of nondimorphic, soilrelated yeasts and molds found in residential areas can cause significant local or systemic human infection, particularly in the immunocompromised. ${ }^{63,69}$ Scedosporium apiospermum is an illustrative example of such a fungus. ${ }^{70} S$. apiospermum may cause local, usually deep, trauma-related infections in normal hosts, colonization or infection of the respiratory tract in persons with predisposing conditions, systemic invasive disease in immunocompromised hosts and pneumonia or brain abscess in near-drowning or trauma victims. ${ }^{69}$

Strains of this fungus and the closely related Pseudallescheria boydii are thermotolerant and have been associated with agricultural, garden, potting or fecesenriched soil, sewers, polluted fresh water and saltwater habitats. ${ }^{70-73}$ S. apiospermum has been isolated preferentially from urban parks, playgrounds and other developed areas compared to natural areas, ${ }^{74}$ including from old decorative bark beneath a home dryer vent in suburban Milwaukee County, Wisconsin. ${ }^{75}$ Other examples include Rhizopus and Mucor spp. (sinus, pulmonary, gastrointestinal and wound infections). Transmissions of these fungi typically occur via sporagiospores in outdoor or indoor air that is inhaled or alighted on open wounds. Victims are usually diabetics or immunocompromised. . $^{7677}$

\section{Fungal Disorders Primarily Acquired Indoors}

The problem of indoor household mold has been an area of active research and controversy the past three decades. Some of this has been fueled by lawsuits and media reports on "toxic mold" and "sick building syndrome." It is difficult to prove cause and effect for these health conditions. Summaries of initial literature on this subject suggest some of these concerns were founded and others not. There is no general dose-response relationship between fungal concentrations and specific human disease. ${ }^{17,21,24}$ Furthermore, fungal species detection and enumeration is dependent on the type of sampling and 
analytic technique used (quantitative polymerase chain reaction may be the most useful to identify associations between particular fungi and disease). ${ }^{78}$

Respiratory Tract Illnesses: Relatively noncontroversial diseases caused by indoor molds include allergic bronchopulmonary aspergillosis (ABPA), allergic sinusitis, and hypersensitivity pneumonitis. Clinical allergic disease due to molds occurs in about $5 \%$ of the total population, and these fungal allergies usually occur in patients with a history of atopy (about $40 \%$ of the U.S. population). The most common allergenic indoor molds are Penicillium and Aspergillus. Cladosporium and Alternaria are predominately outdoor molds commonly found in indoor air and may provoke allergy. ${ }^{17,21,22}$ Allergic symptoms are often more prevalent in people living in damp residences. ${ }^{17}$ Humidity and warmer indoor air promote the growth of both mold (Figure 2) and house dust mites (a common allergen). Molds also serve as food for Dermatophagoides dust mites, further complicating the assignment of allergic etiologic factors. ${ }^{21}$

The role of the fungal cell wall components, chitin and $\beta$-glucans in allergy is unclear. Human studies are limited. ${ }^{17,79}$ Smaller chitin fragments appear to be protective of allergic responses in animal models,

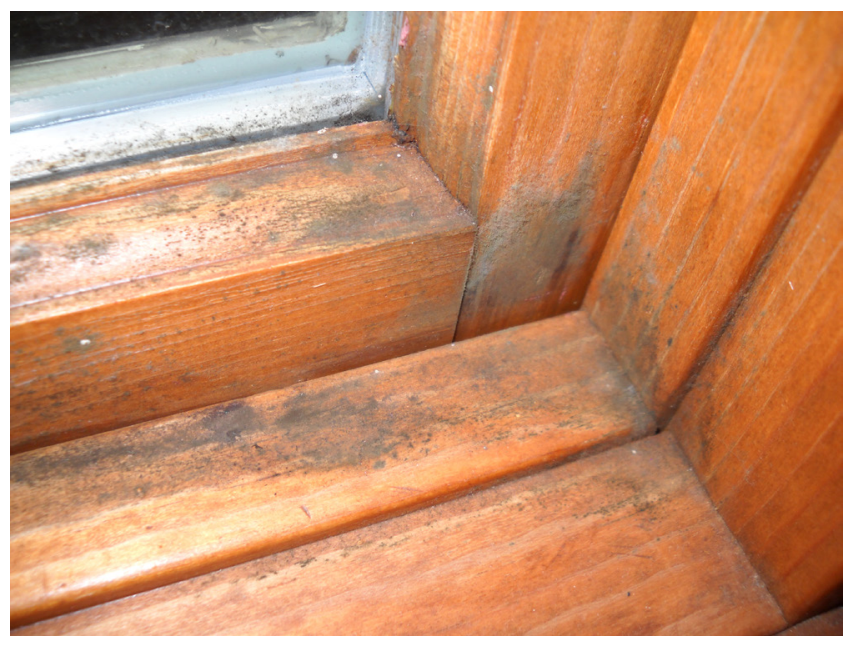

Figure 2. Unidentified mold growing on a household windowsill in Milwaukee County, Wisconsin, in the month of February. This is a common occurrence in winter in the upper Midwest due to condensation at the window interface between warmer, moist indoor air and very cold outdoor air. however, some studies in human cells and nasal passages are contradictory. $\beta$-glucans have been shown to be both proinflammatory and anti-inflammatory. ${ }^{80}$

Fungal hypersensitivity pneumonitis results from an exaggerated normal immunoglobulin $G$ immune response to inhaled fungal proteins in conjunction with inhalation of a very large quantity of such fungal proteins. The interaction between the inhaled proteins and the fungus-directed, cell-mediated antibody reaction leads to an intense local immune response manifested as chronic pneumonitis of the peripheral airways and interstitium. Hypersensitivity pneumonitis has been linked to humidifiers and HVAC systems (most cases are occupational in origin). Humidifier exposures are more often due to filamentous bacteria rather than fungi. ${ }^{21,22}$

Previous literature has associated indoor fungal exposure with more respiratory tract illnesses in infants and children ${ }^{17}$ and with increased asthma occurrence and severity (as well as subsequent improvement after household mold remediation). ${ }^{81}$ More recent studies applying the environmental relative moldiness index (ERMI) to homes have shown an association between higher ERMI score and severe asthma versus no asthma (but not versus moderate asthma) in household children in Detroit, ${ }^{82}$ and between the ERMI and later respiratory illnesses in atopic infants born in the Cincinnati area. ${ }^{83}$ The summation of levels of three molds (two Aspergillus species and one Penicillium) was significantly associated with the development of asthma at age 7 years in infants from this same area who were studied, along with their homes, beginning at age 1 year. ${ }^{84}$ This same authorship group subsequently noted that the home characteristics of air conditioning (negatively), carpeting (negatively), age of home (positively) and dust mite allergen (positively) were associated with the ERMI. Several variables were confounded, and multivariate analysis suggested that lower overall socioeconomic status was associated with higher ERMI. ${ }^{85}$ Similar associations of certain indoor molds with asthma and allergic symptoms (particularly when mold odor was present) were found in single studies and meta-analyses from other Midwestern and worldwide locations. ${ }^{85-92}$

Toxic and Irritant Effects: Controversial concerns regarding indoor molds are especially focused around toxic effects. The major concerns are: 1) mycotoxins, 
which are relatively large, generally nonvolatile molecules (i.e. require inhalation of aerosols of fungal fragments, spores or large molecules) that are not required for fungus growth or survival but often assist in microbial competition; and 2) volatile organic compounds (VOCs) released by molds. The latter is responsible for the characteristic moldy odor. In the United States, acute mold poisonings are uncommon and mostly result from eating mold-contaminated food or by acute inhalations of high concentrations of mold particles or mycotoxins as part of agricultural or other occupational exposure. Indoor residential mold toxicity appears to be much less common and poorly documented. ${ }^{17,21-23}$ Mycotoxins may persist long after fungal particles are nonviable and may only become a problem when dusts are formed. In addition, there are numerous toxins and a poor understanding of their genetic control and potential effects. Thus, it is difficult to relate most toxins to specific symptoms. ${ }^{22}$

There has been particular interest in the trichothecene mycotoxins of Stachybotrys chartarum and its related species since a mid-1990s outbreak of acute pulmonary hemorrhage in Cleveland, Ohio, infants was initially associated with this fungus. ${ }^{21,93}$ While Stachybotrys spp. have been isolated from other substrates, including gypsum (drywall), fiberglass wallpaper and aluminum foil, it has an affinity for water-damaged cellulose. However, this latter substance also promotes the growth of Cladosporium, Penicillium and Aspergillus. In nutrient-poor, damp-cellulose environments, Stachybotrys is a tertiary colonizer following the primary (Penicillium and Aspergillus versicolor) and secondary (Cladosporium) fungal inhabitants. This fact alone makes association of Stachybotrys with human disease difficult, ${ }^{24}$ and many other molds are capable of producing mycotoxins. ${ }^{21}$ The presence of toxigenic molds in a household does not prove the presence of mycotoxins or that the occupants were exposed to a toxic dose. ${ }^{22}$ Recently it has been proposed that molds from water-damaged buildings may reside internally only in biofilms, likely in the sinuses. These molds may continue to release and produce mycotoxins that contribute to ongoing illness. ${ }^{94}$

Within 10 years of the Cleveland outbreak, considerable doubt had been placed on the likelihood of Stachybotrys toxicity due to serious methodological flaws, difficulty assessing mycotoxin levels in homes and lack of other supporting evidence, ${ }^{21,22,24}$ although some investigators remain more favorable toward this epidemiologic association. $^{93}$

Fungal VOCs may cause direct surface irritation that manifests as a burning sensation of the skin, eyes and upper airways. These compounds also have been suggested to cause symptoms such as lethargy and headache, but these effects have not been confirmed by controlled studies. It is more difficult to explain other symptoms such as dizziness, memory loss, gastrointestinal symptoms and muscle cramps. The contribution to these symptoms of potential psychological responses to VOCs notwithstanding, there is little scientific evidence for VOC causality. As with many fungal diseases, individual differences in susceptibility may lead to discordant symptom histories from equally exposed persons. ${ }^{17}$

Sick building syndrome is a controversial concept defined as nonspecific symptoms of the eyes, skin and upper airways, headaches and fatigue of uncertain cause, all of which the patient associates with the indoor environment (though not necessarily fungi). It is more common among women and those with selfreported allergy or with certain personality traits such as somatization and neuroticism. ${ }^{79}$ There is substantial overlap of this concept and other controversial fungusrelated concerns discussed earlier.

\section{Fungal Disease Acquired in all Residential Settings}

Aspergillosis: Conditions caused by Aspergillus may occur from indoor or outdoor exposures, be acute or chronic and have allergic or toxinmediated manifestations. Most infections occur in immunocompromised patients, usually due to Aspergillus fumigatus, and include invasive pulmonary aspergillosis (cough, dyspnea with or without fever, chest pain, hemoptysis, wheezing - symptoms often confused with other entities), pulmonary or sinus fungus balls, chronic pulmonary aspergillosis, allergic fungal sinusitis, invasive sinusitis, posttraumatic keratitis, otomycosis (benign growth on external auditory canal debris), endocarditis and other local, superficial or disseminated forms. ${ }^{95,96}$ Which manifestation of Aspergillus-related disease occurs, if any, following 
exposure depends upon the quantity and virulence of the encountered strain and the host response. ${ }^{97}$

Forms of chronic pulmonary aspergillosis (e.g. simple aspergilloma, chronic cavitary pulmonary aspergillosis, chronic necrotizing pulmonary aspergillosis) are uncommon and nearly always occur in those with underlying chronic obstructive pulmonary disease, diabetes or other immunosuppressive states. Patients usually present with chronic relapsing cough, dyspnea and weight loss. Chest pain, fatigue, fever and acute hemoptysis also may occur. ${ }^{98}$

Allergic bronchopulmonary aspergillosis is a pulmonary manifestation of allergy to A. fumigatus in rural and urban asthmatics that may start in childhood and remain unrecognized for years (some advocate screening all asthmatics for ABPA). The process begins with sensitization in an asthmatic who remains in good control but may progress to steroid-dependent asthma, then to end-stage fibrotic pulmonary disease and "honeycomb lung." Some patients experience a prolonged remission. Aspergillus allergic disease also complicates cystic fibrosis, but laboratory and clinical features are distinct. .6,97 $^{96}$

Most infections occur following inhalation of conidia. Aspergillus is ubiquitous in air, and sources of spores include soil, decaying vegetation and dust. The relative importance of soil as a source of infection compared to plants, flowers, building materials, water and other environments is unclear. ${ }^{11,99}$ Aspergillus fungi were commonly isolated from refrigerator surfaces and foods, pillows, ${ }^{20}$ laundered socks, ${ }^{100}$ composted wood chips and yard waste. ${ }^{96}$ Sputum isolations of $A$. fumigatis have been associated with higher levels of the fungus in the air inside patient homes (although correlation with $A$. fumigates sensitization was not demonstrated). ${ }^{101}$

Fusariam: Fusarium spp. may cause many of the nonallergic manifestations seen with Aspergillus, frequently in immunocompromised persons. Fusarium is found worldwide in soil, water, decaying organic debris and on plants and is spread by air or rain. Infection, and perhaps hypersensitivity pneumonitis, may be acquired at home. ${ }^{102,103}$

Black Fungi: Phaeohyphomycosis is a term applied to clinical syndromes caused by fungi containing high levels of melanin, exclusive of eumycetoma and chromoblastomycosis. Diseases that characterize phaeohyphomycosis include allergic fungal sinusitis and allergic bronchopulmonary mycosis similar to that of Aspergillus, superficial infections (often starting as a single inflammatory cyst on an extremity), deep local infections (often related to trauma or immunosuppression), disseminated infections (usually in the immunocompromised), pulmonary disease (usually in immunocompromised patients or those with underlying lung disease) and central nervous system infection (often in normal hosts). Melanin appears to be a virulence factor in complex, multifactorial and incompletely understood ways. ${ }^{104-106}$

A variety of genera may be agents of phaeohyphomycosis. Three examples are given here. Alternaria and Cladosporium are ubiquitous fungi commonly found in outdoor and indoor air. Both may cause chronic allergic sinusitis in normal hosts. The former has caused ulcerated cutaneous infections, visceral infections, osteomyelitis, keratitis, onychomycosis and invasive sinusitis in immunocompromised individuals, especially those with bone marrow transplants. The latter rarely causes similar disease and pulmonary infections. ${ }^{104,105}$ Exophiala (black yeasts) may cause a variety of deep and cutaneous infections, sinusitis and rare other entities in normal and immunocompromised hosts. ${ }^{104,105,107}$ Infections by these fungi may be underdiagnosed in the United States. ${ }^{107}$ They may be found in water, soil, plants and decaying woody material. Indoors, Exophiala may be identified in dishwashers, ${ }^{13}$ sink drains, bathwater, ${ }^{12}$ and other bathroom and shower surfaces (along with Cladosporium). ${ }^{108}$ Infection by Exophiala occurs by traumatic inoculation and rarely by inhalation. ${ }^{105}$

\section{Prevention}

A recent commentary from the Centers for Disease Control and Prevention pointed out that "fungal infections remain serious and underappreciated causes of illness and death." 109 Prevention of sequelae from these infections includes clinician and public awareness.

Immunocompromised patients should be especially warned regarding risks for fungal infection and ways to prevent fungal exposure. In the domestic environment, this would include maintaining proper personal skin 
integrity and hand hygiene before eating or handling food, after going outdoors and after touching plants, pets or soil. Household measures include keeping water-exposed surfaces and areas of dust accumulation cleaned and disinfected where appropriate, avoiding standing water, using sterile water in nebulizers and humidifiers, and removing water-damaged materials. It is best to avoid home (or yard) renovation, attics, crawl spaces, excavation, caves and musty areas during immunosuppression. ${ }^{110}$ There is moderate evidence that remediation of moldy houses reduces asthma symptoms and respiratory infections, ${ }^{111}$ but controlled trials regarding allergic rhinitis have been few and nonconfirmatory. ${ }^{17,111}$ Mold spores are present in all outdoor and indoor environments and cannot be eliminated. ${ }^{22}$

General measures for all persons to reduce the risk of domestically acquired fungal disease include maintaining relative humidity below $60 \%$ and limiting shower and pot-boiling times, the number of plants to be watered and the use of exhaust fans. Cold surfaces, such as windowsills in winter, promote mold growth. Visible mold in the home should be removed, with particular attention to the underlying cause of excessive moisture. In particular, water leaks should be remediated immediately, and proper HVAC system maintenance ensured. Health departments are often helpful in guiding home remediation. Commercial mold remediation companies may be used if qualified and ethical. . $^{17,22,110}$

\section{Summary}

A variety of fungal microorganisms are capable of departing a soil environment and causing serious focal or systemic infection in humans. Specific evolved virulence factors for the ability to grow in diverse, sometimes harsh, domestic microenvironments may promote infection acquired on one's personal property. Although many of the fungal diseases listed in this article are uncommon, they can occur in individuals largely restricted to a domestic environment in the Midwest. Delay in diagnosis from dismissing a disease such as blastomycosis or failing to consider a fungal etiology for a deep wound infection due to the apparent lack of traditional outdoor recreational or occupational risk factors may lead to patient morbidity or mortality. If a home- or yard-related fungal infection is discovered, source investigation may be an important public health measure. Similarly, in patients who present with self-described mold-related illnesses, an appropriate differential diagnosis should be followed and other causes of the particular complaints ruled out.

\section{Patient-Friendly Recap}

- Myriad fungal spores live in Midwestern homes and yards and can occasionally cause serious infections in residents.

- The author reviewed more than 100 sources to identify the most notable disease-causing domestic fungi (excluding contaminated food or toiletries) and related symptoms.

- Delay in diagnosis can be avoided if clinicians learn to spot the signs of these often challenging fungal infections.

\section{Conflicts of Interest}

None.

\section{References}

1. Robert VA, Casadevall A. Vertebrate endothermy restricts most fungi as potential pathogens. J Infect Dis. 2009;200:1623-6. CrossRef

2. Casadevall A. Fungal virulence, vertebrate endothermy, and dinosaur extinction: is there a connection? Fungal Genet Biol. 2005;42:98-106. CrossRef

3. Warren CPW. Overview of respiratory health risks in agriculture. In: Dosman JA, Cockcroft DW (eds). Principles of Health and Safety in Agriculture. Boca Raton, FL: CRC Press, 1989, pp. 47-9.

4. Maier RM, Pepper IL, Gerba CP (eds). Environmental Microbiology, Second Edition. Burlington, MA: Elsevier Academic Press, 2009, pp. 70-80, 357-63, 445-7.

5. Voroney RP. The soil habitat. In: Paul EA (ed). Soil Microbiology, Ecology and Biochemistry, Third Edition. Burlington, MA: Elsevier Academic Press, 2007, pp. 25-49.

6. Weinberg ED. The influence of soil on infectious disease. Experientia. 1987;43:81-7. CrossRef

7. Barton LL, Northrup DE. Microbial Ecology. Hoboken, NJ: Wiley-Blackwell, 2011, pp. 111-7.

8. Berg G, Eberl L, Hartmann A. The rhizosphere as a reservoir for opportunistic human pathogenic bacteria. Environ Microbiol. 2005;7:1673-85. CrossRef

9. Baumgardner DJ. Soil-related bacterial and fungal infections. J Am Board Fam Med. 2012;25:734-44. CrossRef

10. Cooney NM, Klein BS. Fungal adaptation to the mammalian host: it's a new world, after all. Curr Opin Microbiol. 2008;11:511-6. CrossRef

11. Bennett JW. Aspergillus: a primer for the novice. Med Mycol. 2009;47 Suppl 1:S5-12. CrossRef 
12. Gostinčar C, Grube M, Gunde-Cimerman N. Evolution of fungal pathogens in domestic environments? Fungal Biol. 2011;115:1008-18. CrossRef

13. Zalar P, Novak M, de Hoog GS, Gunde-Cimerman N. Dishwashers - a man-made ecological niche accommodating human opportunistic fungal pathogens. Fungal Biol. 2011;115:997-1007. CrossRef

14. Gostinčar C, Grube M, de Hoog S, Zalar P, Gunde-Cimerman N. Extremotolerance in fungi: evolution on the edge. FEMS Microbiol Ecol. 2010;71:2-11. CrossRef

15. Baumgardner DJ. Microecology of Blastomyces dermatitidis: the ammonia hypothesis. Med Mycol. 2009;47:745-52. CrossRef

16. Chandra J, Kuhn DM, Mukherjee PK, Hoyer LL, McCormick T, Ghannoum MA. Biofilm formation by the fungal pathogen Candida albicans: development, architecture, and drug resistance. J Bacteriol. 2001;183:5385-94. CrossRef

17. Portnoy JM, Kwak K, Dowling P, VanOsdol T, Barnes C. Health effects of indoor fungi. Ann Allergy Asthma Immunol. 2005;94:313-20. CrossRef

18. Miranda ML, Galeano MAO, Hale B, Thomann WR. Crawl spaces as reservoirs for transmission of mold to the livable part of the home environment. Rev Environ Health. 2011;26: 205-13.

19. Adams RI, Miletto M, Taylor JW, Bruns TD. The diversity and distribution of fungi on residential surfaces. PLoS One. 2013;8:e78866. CrossRef

20. Woodcock AA, Steel N, Moore CB, Howard SJ, Custovic A, Denning DW. Fungal contamination of bedding. Allergy. 2006;61:140-2. CrossRef

21. Chapman JA, Terr AI, Jacobs RL, Charlesworth EN, Bardana EJ Jr. Toxic mold: phantom risk vs science. Ann Allergy Asthma Immunol. 2003;91:222-32. CrossRef

22. Hardin BD, Kelman BJ, Saxon A. Adverse human health effects associated with molds in the indoor environment. $J$ Occup Environ Med. 2003;45:470-8.

23. Bennett JW, Klich M. Mycotoxins. Clin Microbiol Rev. 2003;16:497-516. CrossRef

24. Khun DM, Ghannoum MA. Indoor mold, toxigenic fungi, and Stachybotrys chartarum: infectious disease perspective. Clin Microbiol Rev. 2003;16:144-72. CrossRef

25. Benedict K, Park BJ. Invasive fungal infections after natural disasters. Emerg Infect Dis. 2014;20:349-55. CrossRef

26. Flynn NM, Hoeprich PD, Kawachi MM, et al. An unusual outbreak of windborne coccidioidomycosis. $N$ Engl $J$ Med. 1979;301:358-61. CrossRef

27. Deepe GS Jr. Histoplasma capsulatum (Histoplasmosis). In: Bennett JE, Dolin R, Blaser MJ (eds). Mandell, Douglas, and Bennett's Principles and Practice of Infectious Diseases, Eighth Edition. Philadelphia: Elsevier Saunders, 2015, pp. 2949-62.e1.

28. Baumgardner DJ, Burdick JS. An outbreak of human and canine blastomycosis. Rev Infect Dis. 1991;13:898-905. CrossRef

29. Kitchen MS, Reiber CD, Eastin GB. An urban epidemic of North American blastomycosis. Am Rev Respir Dis. 1977;115:1063-6.

30. Cano MV, Hajjeh RA. The epidemiology of histoplasmosis: a review. Semin Resp Infect. 2001;16:109-18. CrossRef

31. Neblett Fanfair R, Benedict K, Bos J, et al. Necrotizing cutaneous mucormycosis after a tornado in Joplin, Missouri, in 2011. N Engl J Med. 2012;367:2214-25. CrossRef
32. Reiss E, Shadomy HJ, Lyon GM III. Histoplasmosis. In: Fundamental Medical Mycology. Hoboken, NJ: WileyBlackwell, 2012, pp. 165-86.

33. Heymann DL (ed). Histoplasmosis. In: Control of Communicable Diseases Manual, 19th Edition. Washington, DC: American Public Health Association, 2008, pp. 305-8.

34. Wheat LJ. Approach to the diagnosis of the endemic mycoses. Clin Chest Med. 2009;30:379-89. CrossRef

35. Lockwood GF, Garrison RG. The possible role of uric acid in the ecology of Histoplasma capsulatum. Mycopathol Mycol Appl. 1968;35:377-88. $\underline{\text { CrossRef }}$

36. Schlech WF 3rd, Wheat JL, Ho JL, et al. Recurrent urban histoplasmosis, Indianapolis, Indiana, 1980-1981. Am J Epidemiol. 1983;118:301-12.

37. Bartlett PC, Vonbehren LA, Tewari RP, et al. Bats in the belfry: an outbreak of histoplasmosis. Am J Public Health. 1982;72:1369-72. CrossRef

38. TaylorML, Ruiz-Palacios GM, delRocío Reyes-Montes M, etal. Identification of the infectious source of an unusual outbreak of histoplasmosis, in a hotel in Acapulco, state of Guerrero, Mexico. FEMS Immunol Med Microbiol. 2005;45:435-41. CrossRef

39. Chick EW, Compton SB, Pass T 3rd, et al. Hitchcock's birds, or the increased rate of exposure to Histoplasma from blackbird roost sites. Chest. 1981;80:434-8. CrossRef

40. Centers for Disease Control and Prevention (CDC). Histoplasmosis outbreak associated with the renovation of an old house - Quebec, Canada, 2013. MMWR Morb Mortal Wkly Rep. 2014;62:1041-4.

41. Fuortes L, Hayes T. An outbreak of acute histoplasmosis in a family. Am Fam Physician. 1988;37:128-32.

42. Byrd RB, Leavey R, Trunk G. The Chanute histoplasmosis epidemic: new variations of urban histoplasmosis. Chest. 1975;6:791-5. CrossRef

43. Bradsher RW Jr. Blastomycosis. In: Bennett JE, Dolin R, Blaser MJ (eds). Mandell, Douglas, and Bennett's Principles and Practice of Infectious Diseases, Eighth Edition. Philadelphia: Elsevier Saunders, 2015, pp. 2963-73.e2.

44. Baumgardner DJ. Blastomycosis. In: Domino FJ, Baldor RA, Golding J, Grimes JA (eds). 5-Minute Clinical Consult 2015, 23rd edition. Philadelphia, PA: Wolters Kluwer Health, 2014 (available online at: https://5minuteconsult. com/collectioncontent/1-151452/diseases-and-conditions/ blastomycosis).

45. Baumgardner DJ, Temte JL, Gutowski E, et al. The differential diagnosis of pulmonary blastomycosis using case vignettes: a Wisconsin Network for Health Research (WiNHR) study. WMJ. 2011;110:68-73.

46. Brown EM, McTaggart LR, Zhang SX, et al. Phylogenetic analysis reveals a cryptic species Blastomyces gilchristii, sp. nov. within the human pathogenic fungus Blastomyces dermatitidis. PLoS One. 2013;8:e59237. CrossRef

47. Baumgardner DJ, Paretsky DP. The in vitro isolation of Blastomyces dermatitidis from a woodpile in north central Wisconsin, USA. Med Mycol. 1999;37:163-8. CrossRef

48. BaumgardnerDJ,LaundreB. Studies on themolecularecologyof Blastomyces dermatitidis. Mycopathologia. 2000;152:51-8. CrossRef

49. Baumgardner DJ, Paretsky DP, Baeseman ZJ, Schreiber A. Effects of season and weather on blastomycosis in dogs: Northern Wisconsin, USA. Med Mycol. 2011;49:49-55. CrossRef 
50. Baumgardner DJ, Bernhard KA, Egan G. Pulmonary blastomycosis in Vilas County, Wisconsin: weather, exposures and symptoms. J Patient Cent Res Rev. 2015;2:25-33. CrossRef

51. Baumgardner DJ, Summerbell R, Krajden S, et al. Attempted isolation of Blastomyces dermatitidis from native shrews in northern Wisconsin, USA. Med Mycol. 2005;43:413-6. CrossRef

52. DiSalvo AF. The ecology of Blastomyces dermatitidis. In: Al-Doory Y, DiSalvo AF (eds). Blastomycosis. New York: Plenum, 1992, pp. 43-73.

53. Baumgardner DJ, Paretsky DP, Yopp AC. The epidemiology of blastomycosis in dogs: north central Wisconsin, USA. $J$ Med Vet Mycol. 1995;33:171-6. CrossRef

54. Bachir J, Fitch GL. Northern Wisconsin married couple infected with blastomycosis. WMJ. 2006;105:55-7.

55. Proctor RA. Infectious diseases in Wisconsin. WMJ. 1998;97:20-2.

56. Proctor RA. Blastomycosis is a serious disease, but let's not raise fears without conclusive data. WMJ. 2001;100:8-9, 34.

57. Blondin N, Baumgardner DJ, Moore GE, Glickman LT. Blastomycosis in indoor cats: suburban Chicago, Illinois, USA. Mycopathologia. 2007;163:59-66. $\underline{\text { CrossRef }}$

58. Baumgardner DJ, Paretsky DP. Blastomycosis: more evidence for exposure near one's domicile. WMJ. 2001;100:43-5.

59. Lowry PW, Kelso KY, McFarland LM. Blastomycosis in Washington Parish, Louisiana, 1976-1985. Am J Epidemiol. 1989;130:151-9.

60. Chapman SW, Lin AC, Hendricks KA, et al. Endemic blastomycosis in Mississippi: epidemiological and clinic studies. Semin Respir Infect. 1997;12:219-28.

61. Roy M, Benedict K, Deak E, et al. A large community outbreak of blastomycosis in Wisconsin with geographic and ethnic clustering. Clin Infect Dis. 2013;57:655-62. CrossRef

62. Denton JF, DiSalvo AF. Additional isolations of Blastomyces dermatitidis from natural sites. Am J Trop Med Hyg. 1979;28:697-700

63. Reiss E, Shadomy HJ, Lyon GM III. Sporotrichosis. In: Fundamental Medical Mycology. Hoboken, NJ: WileyBlackwell, 2012, pp. 215-32.

64. Chakrabarti A, Bonifaz A, Gutierrez-Galhardo MC, Mochizuki T, Li S. Global epidemiology of sporotrichosis. Med Mycol. 2015;53:3-14. CrossRef

65. de Meyer EM, de Beer ZW, Summerbell RC, et al. Taxonomy and phylogeny of new wood- and soil-inhabiting Sporothrix species in the Ophiostoma stenoceras-Sporothrix schenckii complex. Mycologia. 2008;100:647-61. CrossRef

66. Centers for Disease Control (CDC). Multistate outbreak of sporotrichosis in seedling handlers, 1988. MMWR Morb Mortal Wkly Rep. 1988;37:652-3.

67. Dooley DP, Bostic PS, Beckius ML. Spook house sporotrichosis: a point-source outbreak of sporotrichosis associated with hay bale props in a Halloween haunted-house. Arch Intern Med. 1997;157:1885-7. CrossRef

68. Mincher J, Baumgardner DJ. Sporotrichosis in eastern Wisconsin. (abstr.) Wisconsin Health Improvement and Research Partnerships Forum, Madison, WI (September 2011). http://www.fammed.wisc. edu/files/webfm-uploads/documents/research/wren/2011 forum/ posters/Jeff\%20Mincher.doc. Accessed March 17, 2016.

69. Chen SC, Blyth CC, Sorrell TC, Slavin MA. Pneumonia and lung infections due to emerging and unusual fungal pathogens. Semin Resp Crit Care Med. 2011;32:703-16. CrossRef
70. Rainer J, De Hoog GS. Molecular taxonomy and ecology of Pseudallescheria, Petriella and Scedosporium prolificans (Microascaceae) containing opportunistic agents on humans. Mycol Res. 2006;110:151-60. CrossRef

71. Cortez KJ, Roilides E, Quiroz-Telles F, et al. Infections caused by Scedosporium spp. Clin Microbiol Rev. 2008;21:157-97. CrossRef

72. Guarro J, Kantarcioglu AS, Horré R, et al. Scedosporium apiospermum: changing clinical spectrum of a therapyrefractory opportunist. Med Mycol. 2006;44:295-327. CrossRef

73. de Hoog GS, Marvin-Sikkema FD, Lahpoor GA, Gottschall JC, Prins RA, Guého E. Ecology and physiology of the emerging opportunistic fungi Pseudallescheria boydii and Scedosporium prolificans. Mycoses. 1994;37:71-8. CrossRef

74. Kaltseis J, Rainer J, De Hoog GS. Ecology of Pseudallescheria and Scedosporium species in their human-dominated and natural environments and their distribution in clinical samples. Med Mycol. 2009;47:398-405. CrossRef

75. Baumgardner DJ, Chaturvedi S, Li X. My Chrysosporium is a Scedosporium. (abstr.) J Patient Cent Res Rev. 2014;1:48-9. CrossRef

76. Vainrub B, Macareno A, Mandel S, Musher DM. Wound zygomycosis (mucormycosis) in otherwise healthy adults. Am J Med. 1988;84:546-8. CrossRef

77. Reiss E, Shadomy HJ, Lyon GM III. Mucormycosis. In: Fundamental Medical Mycology. Hoboken, NJ: WileyBlackwell, 2012, pp. 431-55.

78. Méheust D, Le Cann P, Reboux G, Millon L, Gangneux JP. Indoor fungal contamination: health risks and measurement methods in hospitals, homes and workplaces. Crit Rev Microbiol. 2014;40:248-60. CrossRef

79. Norbäck D. An update on sick building syndrome. Curr Opin Allergy Clin Immunol. 2009;9:55-9. CrossRef

80. Catalli A, Kulka M. Chitin and $\beta$-glucan polysaccharides as immunomodulators of airway inflammation and atopic disease. Recent Pat Endocr Metab Immune Drug Discov. 2010;4:175-89. CrossRef

81. Jaakkola MS, Jaakkola JJ. Indoor molds and asthma in adults. Adv Appl Microbiol. 2004;55:309-38. CrossRef

82. Vesper S, McKinstry C, Haugland R, et al. Higher Environmental Relative Moldiness Index (ERMIsm) values measured in Detroit homes of severely asthmatic children. Sci Total Environ. 2008;394:192-6. CrossRef

83. Vesper SJ, McKinstry C, Haugland RA, et al. Relative moldiness index as predictor of childhood respiratory illness. J Expo Sci Environ Epidemiol. 2007;17:88-94. CrossRef

84. Reponen T, Lockey J, Bernstein DI, et al. Infant origins of childhood asthma associated with specific molds. J Allergy Clin Immunol. 2012;130:639-44.e5. CrossRef

85. Reponen T, Levin L, Zheng S, et al. Family and home characteristics correlate with mold in homes. Environ Res. 2013;124:67-70. CrossRef

86. Meng J, Barnes CS, Rosenwasser LJ; Children's Mercy Center for Environmental Health. Identity of the fungal species present in the homes of asthmatic children. Clin Exp Allergy. 212;42:1448-58. CrossRef

87. Vesper S, Barnes C, Ciaccio CE, et al. Higher Environmental Relative Moldiness Index (ERMI) values measured in homes of asthmatic children in Boston, Kansas City, and San Diego. J Asthma. 2013;50:155-61. CrossRef 
88. Bundy KW, Gent JF, Beckett W, et al. Household airborne Penicillium associated with peak expiratory flow variability in asthmatic children. Ann Allergy Asthma Immunol. 2009;103:26-30. CrossRef

89. Jaakkola MS, Quansah R, Hugg TT, Heikkinen SA, Jaakkola JJ. Association of indoor dampness and molds with rhinitis risk: a systematic review and meta-analysis. J Allergy Clin Immunol. 2013;132:1099-110.e18. CrossRef

90. Quansah R, Jaakkola MS, Hugg TT, Heikkinen SA, Jaakkola JJ. Residential dampness and molds and the risk of developing asthma: a systematic review and meta-analysis. PLoS One. 2012;7:e47526. CrossRef

91. Tischer C, Chen CM, Heinrich J. Association between domestic mould and mould components, and asthma and allergy in children: a systematic review. Eur Respir J. 2011;38:812-24. CrossRef

92. Shenassa ED, Daskalakis C, Liebhaber A, Braubach M, Brown MJ. Dampness and mold in the home and depression: an examination of mold-related illness and perceived control of one's home as possible depression pathways. Am J Public Health. 2007;97:1893-9. CrossRef

93. Etzel RA. Stachybotrys. Curr Opin Pediatr. 2003;15:103-6. CrossRef

94. Brewer JH, Thrasher JD, Hooper D. Chronic illness associated with mold and mycotoxins: is naso-sinus fungal biofilm the culprit? Toxins (Basel). 2014;6:66-80. CrossRef

95. Boucher HW, Patterson TF. Aspergillosis. In: Hospenthal DR, Rinaldi MG (eds). Diagnosis and Treatment of Human Mycoses. Totowa, NJ: Humana Press, 2008, pp.181-99. CrossRef

96. Reiss E, Shadomy HJ, Lyon GM III. Aspergillosis. In: Fundamental Medical Mycology. Hoboken, NJ: WileyBlackwell, 2012, pp. 357-96.

97. Agarwal R, Chakrabarti A. Allergic bronchopulmonary aspergillosis in asthma: epidemiological, clinical and therapeutic issues. Future Microbiol. 2013;8:1463-74. CrossRef

98. Schweer KE, Bangard C, Hekmat K, Cornely OA. Chronic pulmonary aspergillosis. Mycoses. 2014;57:257-70. CrossRef

99. Hajjeh RA, Warnock DW. Counterpoint: invasive aspergillosis and the environment - rethinking our approach to prevention. Clin Infect Dis. 2001;33:1549-52. CrossRef

100. Amichai B, Grunwald MH, Davidovici B, Farhi R, Shemer A. The effect of domestic laundry processes on fungal contamination of socks. Int J Dermatol. 2013;52:1392-4. CrossRef
101. Fairs A, Agbetile J, Bourne M, et al. Isolation of Aspergillus fumigatus from sputum is associated with elevated airborne levels in homes of patients with asthma. Indoor Air. 2013;23:275-84. CrossRef

102. Gorman SR, Magiorakos AP, Zimmerman SK, Craven DE. Fusarium oxysporum pneumonia in an immunocompetent host. South Med J. 2006;99:613-6. CrossRef

103. Lee SK, Kim SS, Nahm DH, et al. Hypersensitivity pneumonitis caused by Fusarium napiforme in a home environment. Allergy. 2000;55:1190-3. CrossRef

104. Revankar SG, Sutton DA. Melanized fungi in human disease. Clin Microbiol Rev. 2010;23:884-928. CrossRef

105. Reiss E, Shadomy HJ, Lyon GM III. Phaeohyphomycosis. In: Fundamental Medical Mycology. Hoboken, NJ: WileyBlackwell, 2012, pp. 493-511.

106. Garnica M, Nucci M, Queiroz-Telles F. Difficult mycoses of the skin: advances in the epidemiology and management of eumycetoma, phaeohyphomycosis and chromoblastomycosis. Curr Opin Infect Dis. 2009;22: 559-63. CrossRef

107. Zeng JS, Sutton DA, Fothergill AW, Rinaldi MG, Harrak MJ, de Hoog GS. Spectrum of clinically relevant Exophiala species in the United States. J Clin Microbiol. 2007;45: 3713-20. CrossRef

108. Lian X, de Hoog GS. Indoor wet cells harbour melanized agents of cutaneous infection. Med Mycol. 2010;48:622-8. CrossRef

109. Brandt ME, Park BJ. Think fungus - prevention and control of fungal infections. Emerg Infect Dis. 2013;19:1688-9. CrossRef

110. Smith CM, Kagan SH. Prevention of systemic mycoses by reducing exposure to fungal pathogens in hospitalized and ambulatory neutropenic patients. Oncol Nurs Forum. 2005;32:565-79. CrossRef

111. Sauni R, Uitti J, Jauhiainen M, Kreiss K, Sigsgaard T, Verbeek JH. Remediating buildings damaged by dampness and mould for preventing or reducing respiratory tract symptoms, infections and asthma (Review). Evid Based Child Health. 2013;8:944-1000. $\underline{\text { CrossRef }}$

(C) 2016 Aurora Health Care, Inc. 